\title{
You’ll never walk alone
}

Vanuit mijn spreekkamer hoor ik een zanger met 'You'll never walk alone' de ouderen in het verzorgings- en verpleeghuis naast onze praktijk moed toezingen. Op de balkons van de woonzorgappartementen dansen echtparen op de muziek, terwijl de bewaker bij de ingang naar ze zwaait.

Het is onwerkelijk. Rutte stelde terecht: de grootste crisis die wij meemaken. Op het moment dat ik dit schrijf, 24 maart, is de onzekerheid groot. Gaan we het redden zonder lockdown? En hoe gaat het na deze ongekende stilstand met onze economie? Wat is de impact daarvan, ook op de gezondheid en zorg? Alles is anders, ook in de praktijk. We zijn in voorbereiding voor de aanval. Al weken elke ochtend corona-overleg, een corona-arts van de dag, coronaspreekuren. We zien alleen nog spoedgevallen of doen urgente zorg. De praktijkondersteuners doen alles telefonisch en helpen bij de telefoon, die bij vlagen superdruk is. Ook de (para)medici in ons gezondheidscentrum, zoals fysiotherapeuten en tandartsen, sluiten hun praktijken noodgedwongen.

We leggen een enorme flexibiliteit aan de dag. In hoog tempo voeren we digitale zorg in met onder andere videoconsulten. We versterken de samenwerking met GGD, ziekenhuizen, spoedpost en hagro volgens het Huisartsen Rampen Opvang Plan. De informatievoorziening is fantastisch: dagelijks krijgen we up-todate informatie. We absorberen en verwerken gewijzigde instructies saamhorig en zonder mopperen.

Ook het NHG pakt zijn rol. Er is dagelijks crisisoverleg met LHV en InEen, een coronateam verzorgt elke dag updates van het digitale coronadossier in afstemming met partijen als RIVM en ministerie. Op Thuisarts.nl wordt nieuwe informatie meteen verwerkt. Vragen van leden worden zo snel mogelijk beantwoord. En dat alles vanuit huis! Alle NHG-medewerkers blijven digitaal hard (samen)werken om u zo goed mogelijk te ondersteunen.

H\&W gaat actuele COVID-19-ontwikkelingen zo snel mogelijk digitaal met $u$ delen via de website en nieuwsbrieven, waarbij eenduidige, praktische en relevante informatie centraal staat. Ondertussen gaan de huisartsenzorg en de wetenschap door, zoals u ook in dit nummer kunt lezen. Terwijl mijn collega na het coronaspreekuur het coronapak uitdoet, ga ik een spoedvisite afleggen voor nierstenen. Denkend aan de zanger vanochtend neurie ik het liedje 'Let's stay together'.

Ivo Smeele, hoofdredacteur HeW

De berichten rond COVID-19 volgen elkaar razendsnel op. Dagelijks vernieuwde up-to-date informatie van belang voor de praktijk vindt u op nhg.org/coronavirus. Voor actuele wetenschappelijke inzichten en discussies verwijzen wij u ook naar de website van het Nederlands Tijdschrift voor Geneeskunde [www.ntvg.nl/covid-19].Deze artikelen zijn voor iedereen toegankelijk. De H\&W-redactie 